\title{
PENGARUH DOSIS PUPUK ORGANIK DAN DOSIS PUPUK ANORGANIK TERHADAP PERTUMBUHAN DAN PRODUKSI PER HEKTAR TANAMAN BAWANG DAUN (Allium fistulosum L)
}

\author{
Edy Wibowo \\ Dosen Tetap Agroteknologi, Universitas Wahidiyah, Kediri \\ *Email Korespondensi : eddygostu@gmail.com
}

\begin{abstract}
Abstrak
Tanaman bawang daun merupakan sayuran yang potensial untuk diusahakan. Salah satu usaha untuk peningkatan produksi bawang daun adalah dengan pemberian nutrisi yang tepat yaitu pupuk organik dan pupuk anorganik yang seimbang. Penelitian ini bertujuan untuk mengetahui pengaruh dosis pupuk organik dan anorganik terhadap pertumbuhan dan produksi per hektar tanaman bawang daun. Penelitian ini dilaksanakan pada bulan Juni sampai bulan Agustus 2021 di Desa Kepuhrejo, Kecamatan Ngantru, Kabupaten Tulungagung. Rancangan penelitian menggunakan Rancangan Acak Kelompok (RAK) dengan 2 faktor, yaitu: Dosis Pupuk Organik (0) dengan 3 taraf yaitu : 01 (5 Ton/HA), 02 (10 Ton/Ha), dan 03 (15 Ton/Ha) dan dosis pupuk Anorganik (A) dengan 3 taraf yaitu A1 (NPK Mutiara $150 \mathrm{~kg} / \mathrm{ha}$ dan ZA $150 \mathrm{~kg} / \mathrm{Ha}$ ), A2 (NPK Mutiara $200 \mathrm{~kg} / \mathrm{ha}$ dan ZA 200 $\mathrm{kg} / \mathrm{Ha}$ ), A3 (NPK Mutiara $250 \mathrm{~kg} / \mathrm{ha}$ dan ZA $250 \mathrm{~kg} / \mathrm{Ha}$ ) dengan 3 kali pengulangan, sehingga terdapat 27 petak percobaan. Pengamatan dilakukan terhadap tinggi tanaman pada umur 15 dan 45 hst, dan produksi tanaman per hektar pada petak perlakuan mulai panen umur 60 hst. Hasil penelitian menunjukkan bahwa dosis pupuk organik 15 Ton/Ha (O3) dan dosis pupuk anorganik NPK Mutiara $250 \mathrm{~kg} / \mathrm{Ha}$ dan ZA $250 \mathrm{~kg} / \mathrm{Ha}$ (A3) memberikan hasil terbaik pada pertumbuhan dan produksi tanaman bawang daun per hektar. Rata-rata pertumbuhan tinggi tanaman yang paling tinggi didapatkan dari perlakuan dosis pupuk organik 15 Ton/Ha (03) yaitu 15,09 cm pada umur 15 hst dan $50,15 \mathrm{~cm}$ pada umur $45 \mathrm{hst}$, juga pada perlakuan dosis pupuk anorganik NPK Mutiara 250 $\mathrm{kg} / \mathrm{Ha}$ dan ZA $250 \mathrm{~kg} / \mathrm{Ha}$ (A3) yaitu 15,14 cm pada umur $15 \mathrm{hst}$ dan $50,18 \mathrm{~cm}$ pada umur 45 hst. Rata-rata produksi per hektar tanaman bawang daun tertinggi dihasilkan oleh perlakuan dosis pupuk organik $15 \mathrm{Ton} / \mathrm{Ha}$ (O3) sebesar 27,17 ton dan perlakuan dosis pupuk anorganik NPK Mutiara $250 \mathrm{~kg} / \mathrm{Ha}$ dan ZA $250 \mathrm{~kg} / \mathrm{Ha}$ (A3) sebesar 27,18 ton.
\end{abstract}

Kata Kunci : Bawang Daun, Dosis Pupuk Organik, Dosis Pupuk Anorganik.

\begin{abstract}
The leek plant (Allium fistulosum L) is a vegetable that has the potential to be cultivated. One of the efforts to increase leek plant production is by providing proper nutrition, namely balanced organic fertilizers and inorganic fertilizers. This study aims to determine the effect of doses of organic and inorganic fertilizers on growth and production per hectare of leek plant. This research was conducted from June to August 2021 in Kepuhrejo Village, Ngantru District, Tulungagung Regency. The research design used a Randomized Block Design (RAK) with 2 factors, namely: Dosage of Organic Fertilizer (O) with 3 levels, namely: 01 (5 Tons/HA), 02 (10 Tons/Ha), and 03 (15 Tons/Ha) and doses of Inorganic fertilizers (A) with 3 levels, namely A1 (NPK Mutiara $150 \mathrm{~kg} / \mathrm{ha}$ and ZA $150 \mathrm{~kg} / \mathrm{Ha}$ ), A2 (NPK Mutiara $200 \mathrm{~kg} / \mathrm{ha}$ and ZA $200 \mathrm{~kg} / \mathrm{Ha}$ ), A3 (NPK Mutiara $250 \mathrm{~kg} / \mathrm{Ha}$ ). ha and ZA $250 \mathrm{~kg} / \mathrm{Ha}$ ) with 3 repetitions, so there were 27 experimental plots. Observations were made on plant height at the age of 15 and 45 $D A P$, and plant production per hectare in treatment plots starting at 60 DAP. The results showed that the dose of organic fertilizer $15 \mathrm{Ton} / \mathrm{Ha}(\mathrm{O3})$ and the dose of inorganic fertilizer
\end{abstract}


NPK Mutiara $250 \mathrm{~kg} / \mathrm{Ha}$ and ZA $250 \mathrm{~kg} / \mathrm{Ha}$ (A3) gave the best results on the growth and production of leek plant per hectare. The highest average plant height growth was obtained from the treatment with a dose of 15 Ton/Ha (O3) organic fertilizer, which was 15,09 cm at the age of 15 DAP and 50,15 cm at the age of 45 DAP, also at the dose of inorganic fertilizer NPK Mutiara $250 \mathrm{~kg} / \mathrm{Ha}$ and ZA $250 \mathrm{~kg} / \mathrm{Ha}(\mathrm{A3})$ which were $15,14 \mathrm{~cm}$ at the age of $15 \mathrm{DAP}$ and 50,18 cm at the age of 45 DAP. The highest average production per hectare of leek plants was produced by treatment with a dose of organic fertilizer $15 \mathrm{Ton} / \mathrm{Ha}(\mathrm{O3})$ of 27,17 tons and a dose of inorganic fertilizer NPK Mutiara $250 \mathrm{~kg} / \mathrm{Ha}$ and ZA $250 \mathrm{~kg} / \mathrm{Ha}$ (A3) of 27,18 tons.

Key Words : leek plant, Organic Fertilizer Dosage, Inorganic Fertilizer Dosage

\section{PENDAHULUAN}

Tanaman bawang daun (Allium fistulosum L) merupakan salah satu tanaman yang dimanfaatkan sebagai bahan bumbu penyedap sekaligus pengharum masakan dan campuran berbagai masakan, selain itu bawang daun merupakan sayuran yang potensial untuk dikembangan, baik di lahan pekarangan maupun budidaya skala besar karena kebutuhan akan bawang daun masih cukup tinggi. Daerah pusat penyebaran bawang daun di Indonesia semula terkonsentrasi pada lahan dataran tinggi dengan udara yang sejuk (suhu rendah) seperti di Cipanas, Pacet (Cianjur), Lembang (Bandung) dan Malang (Jawa Timur). Dalam perkembangan selanjutnya, budidaya bawang daun meluas ke berbagai daerah (wilayah) di seluruh nusantara, baik ditanam di dataran tinggi maupun di dataran rendah (Rukmana, 1995).

Kebutuhan akan bawang daun secara nasional tercatat mengalami fluktuasi, dari data BPS bahwa produksi bawang daun tahun 2017 sebesar 510.476 Ton, dan mengalami peningkatan yang signifikan pada tahun 2018 sebesar 573.228 Ton dan tahun 2019 sebesar 590.596 Ton. Kemudian mengalami penurunan pada tahun 2020 yaitu 579.748 Ton. Hal ini sebagian besar disebabkan lesunya pasar karena pandemi Covid19 dan penurunan produksi akibat faktor tanah yang semakin mengalami penurunan kesuburan (BPS.go.id, 2020). Kesuburan tanah merupakan faktor penting dalam proses budidaya tanaman karena awal dari pertumbuhan tanaman diawali dari tanah. Kemampuan tanah dalam berproduksi didukung dari 3 unsur penting yaitu sifat biologi tanah, sifat fisika dan sifat kimia tanah. Untuk menunjang ketiga unsur penting tersebut perlu adanya nutrisi yang seimbang untuk diberikan kepada tanah dalam menunjang pertumbuhan tanaman yaitu pemupukan (Hanafiah, 2007).

Perbaikan kesuburan tanah antara lain dilakukan dengan pemupukan baik berupa pupuk organik atau anorganik. Pemberian pupuk organik dapat memperbaiki sifat fisik, kimia, dan biologi tanah (Leszczynska dan Malina, 2011). Pemberian pupuk organik dapat meningkatkan daya menahan air dan kapasitas tukar kation tanah sehingga apabila ditambahkan pupuk anorganik maka pencucian oleh air hujan dan erosi dapat dihambat (Prasetyo dan Suriadikarta, 2006). Pemberian pupuk anorganik dimaksudkan untuk memenuhi kebutuhan hara yang tidak dapat disediakan oleh tanah. Unsur hara N, P, dan K merupakan tiga unsur hara makro utama yang dibutuhkan tanaman.

Pupuk organik merupakan pupuk yang umumnya digunakan dalam budidaya tanaman. Keistimewaan dari pupuk organik adalah dapat memperbaiki sifat-sifat fisik tanah (memperbaiki struktur tanah, porositas, permeabilitas, meningkatkan kemampuan untuk menahan air, dan lain-lain), sifat kimia (meningkatkan kemampuan tanah untuk menjerap kation, sebagai sumber hara makro dan mikro, dan pada tanah masam dapat menaikkan $\mathrm{pH}$ dan menekan kelarutan aluminium dengan membentuk kompleks Albahan organik) dan sifat biologi tanah (meningkatkan aktivitas mikroba tanah dan sebagai sumber energi bagi bakteri penambat N2 dan pelarut fosfat, dan lain-lain). Salah satu jenis pupuk kandang yang 
sering digunakan adalah pupuk dari kambing yang mengandung unsur $\mathrm{N}$ cukup tinggi (Lingga et al, 2006).

Pupuk organik memiliki kandungan unsur hara yang lebih rendah dibanding pupuk anorganik. Oleh karena itu untuk memenuhi kebutuhan unsur hara dan untuk meningkatkan produksi bawang daun diperlukan pupuk anorganik sebagai tambahan. Penambahan pupuk anorganik berperan penting pada pertumbuhan dan produksi tanaman. Pupuk anorganik menyediakan unsur hara esensil yang dibutuhkan tanaman dalam kadar yang jelas sehingga mampu mendukung pertumbuhan tanaman secara optimal. Penggunaan pupuk seimbang antara unsur N, P, dan K memberikan hasil yang baik untuk pertumbuhan tanaman. Secara umum untuk menunjang pertumbuhan tanaman bawang daun dibutuhkan unsur Nitrogen yang tinggi sehingga hal tersebut dapat dipenuhi dari pemberian tambahan pupuk dengan kandungan Nitorgen dari pupuk anorganik (Cahyono, 2011).

Tujuan penelitian ini adalah untuk mengetahui pengaruh dosis pupuk organik dan pupuk anorganik terhadap pertumbuhan dan produksi per hektar tanaman bawang daun.

\section{METODE PENELITIAN}

Penelitian ini dilaksanakan pada bulan Juni sampai dengan bulan Agustus 2021 di Desa Kepuhrejo, Kecamatan Ngantru, Kabupaten Tulungagung, ketinggian tempat sekitar 87 meter diatas permukaan laut (MDPL), kelembaban udara 60-70\%, jenis tanah alluvial dengan PH 6,4. Bahan-bahan yang digunakan dalam penelitian ini adalah: bibit bawang daun varietas Fragrant, pupuk organik berupa pupuk kompos kambing jadi, pupuk anorganik berupa pupuk NPK Mutiara dan ZA, dan pestisida. Sedangkan alat yang digunakan adalah cangkul, sabit, gembor, timba, $\mathrm{pH}$ meter, alat ukur tinggi, timbangan digital,sprayer, papan nama, alat tulis dan dokumentasi. Penelitian ini menggunakan Rancangan Acak Kelompok (RAK) dengan pola faktorial terdiri dari 2 faktor, yaitu : Dosis Pupuk Organik (O) dengan 3 taraf yaitu: 01 (5 Ton/HA), 02 (10 Ton/Ha), dan 03 (15 Ton/Ha) dan dosis pupuk Anorganik. (A) dengan 3 taraf yaitu A1 (NPK Mutiara $150 \mathrm{~kg} / \mathrm{ha}$ dan ZA $150 \mathrm{~kg} / \mathrm{Ha}$ ), A2 (NPK Mutiara $200 \mathrm{~kg} / \mathrm{ha}$ dan ZA $200 \mathrm{~kg} / \mathrm{Ha}$ ), A3 (NPK Mutiara 250 $\mathrm{kg} / \mathrm{ha}$ dan ZA $250 \mathrm{~kg} / \mathrm{Ha}$ ) dengan 3 kali pengulangan, sehingga terdapat 27 petak percobaan. Perlakuan dosis pupuk organik diaplikasikan sebelum tanam beserta pengolahan lahan sesuai dosis pada petak penelitian, sedangkan perlakuan pupuk anorganik dilakukan dua kali yaitu aplikasi pertama pupuk NPK Mutiara sesuai dosis pada umur 10 hst dan aplikasi kedua menggunakan pupuk ZA sesuai dosis pada umur 40 hst dengan cara ditugal disela antar tanaman. Setiap petak percobaan ukuran 100 x $500 \mathrm{~cm}$ dengan jarak tanam $12 \times 20 \mathrm{~cm}$ sehingga terdapat 500 tanaman per petak perlakuan dengan 30 tanaman sebagai sampel pengamatan tanaman sehingga jumlah total tanaman yang digunakan dalam penelitian ini sebanyak 540 tanaman. Pengamatan dilakukan terhadap tinggi tanaman pada umur 15 dan 45 hst sebagai parameter pertumbuhan, dan pengamatan saat panen umur 60 hst sebagai parameter produksi per hektar (Ton).

\section{HASIL DAN PEMBAHASAN Tinggi Tanaman}

Dalam Penelitian ini parameter pertumbuhan tanaman adalah tinggi tanaman bawang daun yang diamati pada umur 15 hst dan 45 hst. Berdasarkan hasil analisis sidik ragam menunjukkan bahwa perlakuan dosis pupuk organik terjadi pengaruh yang sangat nyata pada data tinggi tanaman pada umur 15 hst dan 45 hst, selanjutnya perlakuan dosis pupuk anorganik juga menunjukkan pengaruh yang sangat nyata pada tinggi tanaman pada umur 15 hst dan 45 hst. 
Tabel 1. Pengaruh Dosis Pupuk Organik terhadap Pertumbuhan Tanaman Bawang Daun

\begin{tabular}{ccc}
\hline Dosis Pupuk Organik (0) & \multicolumn{2}{c}{ Rata-Rata Tinggi Tanaman (Cm) } \\
\cline { 2 - 3 } & 15 HST & 45 HST \\
\hline 01 & $14,56 \mathrm{a}$ & $49,57 \mathrm{a}$ \\
02 & $14,80 \mathrm{~b}$ & $49,80 \mathrm{~b}$ \\
03 & $15,09 \mathrm{c}$ & $50,15 \mathrm{c}$ \\
\hline
\end{tabular}

Keterangan : - Angka rata-rata yang diikuti oleh huruf yang sama pada kolom yang sama menunjukkan hasil yang tidak berbeda nyata menurut Uji Beda Nyata Terkecil (BNT) pada taraf 5\%.

- HST = Hari Setelah Tanam.

Berdasarkan Tabel 1. hasil uji BNT 5\% pada tinggi tanaman umur 15 hst pemberian pupuk organik menunjukkan hasil terbaik pada perlakuan 03 yaitu dosis 15 Ton/Ha sebesar 15,09 cm berbeda nyata dengan perlakuan 02 sebesar 14,80 cm dan pelakuan 01 sebesar 14,56 cm. Selanjutnya pada pengamatan umur 45 hst pemberian pupuk organik menunjukkan hasil terbaik pada perlakuan 03 yaitu dosis 15 Ton/Ha sebesar 50,15 cm berbeda nyata dengan perlakuan 02 sebesar 49,80 cm dan pelakuan 01 sebesar 49,57 cm. Hal ini disebabkan pemberian pupuk organik kompos limbah kambing mengandung kadar nitrogen yg cukup tinggi sehingga mampu memacu pertumbuhan tanaman karena unsur Nitrogenberperan penting pada proses pertumbuhan tanaman. Nitrogen diserap tanaman dalam bentuk ion nitrat (NO3) dan ion ammonium (NH4+). Nitrogen dibutuhkan untuk membentuk senyawa penting seperti klorofil, asam nukleat dan enzim, karena itu $\mathrm{N}$ dibutuhkan dalam jumlah relatif besar pada setiap pertumbuhan tanaman, khususnya pada pertumbuhan vegetatif (Lingga et al, 2006). Didukung pula kadar bahan organik yang cukup melimpah dari pupuk kompos memberikan suplay bahan organik kedalam tanah. Bahan organik merupakan salah satu elemen penting dalam tanah yang berperan dalam keseimbangan kesuburan tanah, meningkatkan kapasitas tukar kation, memberikan daya ikat yang baik bagi tanah untuk menjerap unsur hara sehingga bisa dimanfaatkan oleh tanaman secara maksimal (Hanafiah, 2007).

Tabel 2. Pengaruh Dosis Pupuk Anorganik terhadap Pertumbuhan Tanaman Bawang Daun

\begin{tabular}{ccc}
\hline Dosis Pupuk Anorganik (A) & \multicolumn{2}{c}{ Rata-Rata Tinggi Tanaman (Cm) } \\
\cline { 2 - 3 } & $\mathbf{1 5}$ HST & \multirow{2}{*}{ 45 HST } \\
\hline A1 & $14,58 \mathrm{a}$ & $49,58 \mathrm{a}$ \\
A2 & $14,73 \mathrm{~b}$ & $49,75 \mathrm{~b}$ \\
A3 & $15,14 \mathrm{c}$ & $50,18 \mathrm{c}$ \\
\hline
\end{tabular}

Keterangan : - Angka rata-rata yang diikuti oleh huruf yang sama pada kolom yang sama menunjukkan hasil yang tidak berbeda nyata menurut Uji Beda Nyata Terkecil (BNT) pada taraf 5\%.

- HST = Hari Setelah Tanam

Berdasarkan Tabel 2. hasil uji BNT 5\% pada tinggi tanaman umur 15 hst pemberian pupuk anorganik menunjukkan hasil terbaik pada perlakuan A3 yaitu dosis NPK Mutiara $250 \mathrm{~kg} / \mathrm{Ha}$ dan ZA $250 \mathrm{~kg} / \mathrm{Ha}$ sebesar 15,14 cm berbeda nyata dengan perlakuan A2 sebesar 14,73 cm dan pelakuan A1 sebesar 14,58 cm. Selanjutnya pada pengamatan umur 45 hst pemberian pupuk anorganik menunjukkan hasil terbaik pada perlakuan A3 yaitu dosis yaitu dosis NPK Mutiara $250 \mathrm{~kg} / \mathrm{Ha}$ dan ZA $250 \mathrm{~kg} /$ Ha sebesar 50,18 cm berbeda nyata dengan perlakuan A2 sebesar 49,75 cm dan pelakuan A1 sebesar 49,58 cm. Hal ini 
disebabkan pemberian pupuk anorganik yang memiliki kadar dan jumlah unsur hara jelas mampu memberikan nutrisi yang cukup untuk mendukung pertumbuhan tanaman. Pemberian pupuk NPK Mutiara sesuai dosis perlakuan diberikan pada saat tanaman umur 10 hari setelah tanam. Hal ini bertujuan agar saat tanaman bawang daun sudah mulai adaptasi dengan lingkungan kemudian start untuk tumbuh, nutrisi $\mathrm{N}, \mathrm{P}$, dan $\mathrm{K}$ tercukupi dengan baik. Unsur $\mathrm{N}$ berperan dalam mempercepat pertumbuhan tanaman (tinggi, jumlah anakan, jumlah cabang), unsur $\mathrm{P}$ berperan dalam memacu pertumbuhan akar dan membentuk sistem perakaran yang baik, menggiatkan pertumbuhan jaringan tanaman yang membentuk titik tumbuh tanaman, dan unsur $\mathrm{K}$ berperan dalam aktivator enzim, membantu penyerapan air dan unsur hara dari tanah oleh tanaman, dan membantu transportasi hasil asimilasi dari daun ke jaringan tanaman. Sedemikian kompleks peran dari unsur N, P, dan $\mathrm{K}$ untuk proses pertumbuhan tanaman maka pemberian pupuk NPK Mutiara ini dilakukan pada pemupukan pertama. Kemudian pada pemupukan kedua diberikan pupuk ZA yang khusus berperan dalam suplai nutrisi nitrogen untuk pertumbuhan lanjutan tanaman bawang daun. Pada tanaman bawang daun yang diambil hasilnya adalah pada daunnya sehingga dibutuhkan unsur nitrogen extra untuk memacu pertumbuhan vegetatifnya. Fungsi nitrogen selain berperang dalam mempercepat pertumbuhan tanaman, juga berperan dalam pembentukan zat hijau daun, sehingga daun lebih hijau dan lebat, serta menambah kandungan protein hasil panen. (Lingga et al, 2006).

\section{Produksi Per Hektar}

Dalam Penelitian ini parameter produksi adalah berat hasil panen tanaman bawang daun (Ton) tiap satuan hektar lahan yang diamati pada saat mulai panen umur 60 hst. Berdasarkan hasil analisis sidik ragam menunjukkan bahwa perlakuan dosis pupuk organik terjadi pengaruh yang sangat nyata pada data produksi ton per hektar tanaman bawang daun, selanjutnya perlakuan dosis pupuk anorganik juga menunjukkan pengaruh yang sangat nyata pada produksi ton per hektar tanaman bawang daun.

Tabel 3. Pengaruh Dosis Pupuk Organik terhadap Produksi Per Hektar (Ton) Tanaman bawang daun

\begin{tabular}{cc}
\hline Dosis Pupuk Organik (0) & Rata-Rata Produksi Per Ha (Ton) \\
\hline 01 & $26,57 \mathrm{a}$ \\
02 & $26,80 \mathrm{~b}$ \\
03 & $27,17 \mathrm{c}$ \\
\hline
\end{tabular}

Keterangan : - Angka rata-rata yang diikuti oleh huruf yang sama pada kolom yang sama menunjukkan hasil yang tidak berbeda nyata menurut Uji Beda Nyata Terkecil (BNT) pada taraf 5\%. - HST = Hari Setelah Tanam

Berdasarkan tabel 3. hasil uji BNT 5\% pada rata-rata produksi per hektar (Ton) pemberian pupuk organik menunjukkan hasil terbaik pada perlakuan 03 yaitu dosis 15 Ton/Ha sebesar 27,17 Ton per Hektar berbeda nyata dengan perlakuan 02 sebesar 26,80 Ton per Hektar dan pelakuan 01 sebesar 26,57 Ton per Hektar. Hal ini disebabkan oleh pemberian bahan organik kedalam tanah memberikan pengaruh yang signifikan terhadap penyerapan unsur hara. Kadar bahan organik yang tinggi pada tanah akan memberikan daya ikat yang baik pada tanah sehingga pemberian pupuk tambahan berupa pupuk NPK Mutiara dan juga pupuk ZA mampu dijerap oleh tanah dan diserap dengan baik oleh tanaman dalam memberikan hasil produksi yang baik pada tanaman bawang daun. Bahan organik berperan penting pada perbaikan sifat-sifat tanah, meliputi sifat fisika, kimia dan 
biologi tanah. Bahan organik merupakan sumber energi bagi aktivitas mikrobia tanah dan dapat memperbaiki berat volume tanah, struktur tanah, aerasi serta daya ikat tanah terhadap air dan unsur hara. Selain itu peran bahan organik dengan hasil dekomposisi berupa humus dapat meningkatkan kesuburan fisik tanah. Humus mempunyai luas permukaan dan kemampuan menyerap air dan unsur hara yang lebih besar (Syukur et al, 2006). Dari data dan uraian tersebut menunjukkan pemberian pupuk organik mampu memberikan hasil yang baik untuk menunjang produksi tanaman secara optimal. Fungsi pupuk organik dari limbah kotoran kambing adalah sebagai penyuplai bahan organik dalam bentuk yang telah dikomposkan bermanfaat untuk meningkatkan kadar bahan organik tanah, memperbaiki kesuburan fisik, kimia, dan biologi tanah, meningkatkan keragaman, populasi dan aktivitas mikroba dan memudahkan penyediaan hara dalam tanah, meminimalisir degradasi lahan karena pemakaian pupuk anorganik secara terus menerus dan menyediakan hara makro dan mikro yang mendukung proses pertumbuhan tanaman (Winarso, 2016).

Tabel 4. Pengaruh Dosis Pupuk Anorganik terhadap Produksi Per Hektar (Ton) Tanaman bawang daun

Dosis Pupuk Anorganik (A) $\quad$ Rata-Rata Produksi Per Ha (Ton)

\begin{tabular}{ll}
\hline A1 & $26,58 \mathrm{a}$ \\
A2 & $26,77 \mathrm{~b}$ \\
A3 & $27,18 \mathrm{c}$ \\
\hline
\end{tabular}

Keterangan : - Angka rata-rata yang diikuti oleh huruf yang sama pada kolom yang sama menunjukkan hasil yang tidak berbeda nyata menurut Uji Beda Nyata Terkecil (BNT) pada taraf 5\%.

- HST = Hari Setelah Tanam

Berdasarkan Tabel 4. hasil uji BNT 5\% pada rata-rata produksi per hektar (Ton) pemberian pupuk anorganik menunjukkan hasil terbaik pada perlakuan A3 yaitu dosis NPK Mutiara $250 \mathrm{~kg} / \mathrm{Ha}$ dan ZA $250 \mathrm{~kg} / \mathrm{Ha}$ sebesar 27,18 Ton per Hektar berbeda nyata dengan perlakuan A2 sebesar 26,77 Ton per Hektar dan pelakuan A1 sebesar 26,58 Ton per Hektar. Hal ini disebabkan dengan menggunakan pupuk dosis A3 dapat mendukung pertumbuhan dan produksi tanaman bawang daun secara maksimal. Unsur hara berperan penting dalam proses produksi tanaman, terutama unsur N, P, dan K. Dengan pemberian pupuk NPK Mutiara sebagai pupuk I atau nutrisi awal dengan dosis A3 terbukti mampu memberikan produksi maksimal, serta didukung dengan pupuk ke II berupa ZA sesuai dosis A3 memberikan booster bagi tanaman bawang daun untuk pembesaran batang dan daun. Hal ini tak lepas dari peranan bahan organik yang cukup tersedia sehingga keseimbangan tanah menjadi lebih baik dan mendukung penyerapan unsur hara yang diaplikasikan ke tanah untuk diserap oleh tanaman (Muslimin et al. 2012). Unsur hara N, $\mathrm{P}$, dan K yang terkandung dalam pupuk NPK majemuk mempunyai peran spesifik, yaitu unsur $\mathrm{N}$ adalah untuk pertumbuhan tanaman secara keseluruhan, yaitu untuk pembentukan protein, sintesis klorofil, dan proses metabolism. Unsur P berperan sebagai unsur pembentuk molekul ATP yang merupakan molekul kaya energi yang dibutuhkan dalam proses metabolisme misalnya sintesis protein, sehingga apabila kekurangan hara $\mathrm{P}$ dapat menyebabkan pertumbuhan terhambat. Unsur K berperan sebagai aktivator enzim memelihara potensial osmosis dan pengambilan air, serta translokasi hasil fotosintesis keluar daun menuju sink (Rachman et al., 2008). 


\section{KESIMPULAN}

1. Dosis pupuk organik dan pupuk anorganik berpengaruh terhadap pertumbuhan dan produksi per hektar tanaman bawang daun.

2. Dosis pupuk organik 15 Ton/Ha (O3) dan dosis pupuk anorganik NPK Mutiara 250 $\mathrm{kg} / \mathrm{Ha}$ dan ZA $250 \mathrm{~kg} / \mathrm{Ha}$ (A3) memberikan hasil terbaik pada pertumbuhan dan produksi tanaman bawang daun per hektar.

3. Rata-rata pertumbuhan tinggi tanaman yang paling tinggi didapatkan dari perlakuan dosis pupuk organik 15 Ton/Ha (O3) yaitu 15,09 cm pada umur $15 \mathrm{hst}$ dan 50,15 cm pada umur $45 \mathrm{hst}$, juga pada perlakuan dosis pupuk anorganik NPK Mutiara $250 \mathrm{~kg} / \mathrm{Ha}$ dan ZA $250 \mathrm{~kg} / \mathrm{Ha}$ (A3) yaitu $15,14 \mathrm{~cm}$ pada umur $15 \mathrm{hst}$ dan $50,18 \mathrm{~cm}$ pada umur $45 \mathrm{hst}$.

4. Rata-rata produksi per hektar tanaman bawang daun tertinggi dihasilkan oleh perlakuan dosis pupuk organik 15 Ton/Ha (03) sebesar 27,17 ton dan perlakuan dosis pupuk anorganik NPK Mutiara $250 \mathrm{~kg} / \mathrm{Ha}$ dan ZA $250 \mathrm{~kg} / \mathrm{Ha}$ (A3) sebesar 27,18 ton.

\section{REFERENSI}

SBPS.go.id. 2020. Data Produksi Sayuran Nasional. https://www.bps.go.id/indicator/55/61/1/produksi-tanaman-sayuran.html

Cahyono, B. 2011. Seri Budidaya Bawang Daun. Kanisius, Yogyakarta. Hanafiah, Kemas Ali. 2007. Dasar-Dasar Ilmu Tanah. Jakarta : PT Raja GrafindoPersada

Leszczynska, D., J.K. Malina. 2011. Effect of organic matter from various sources on yield and quality of plant on soils contaminated with heavy metals. Ecol. Chem. Eng. S. 18:501-507.

Lingga dan Marsono. 2006. Petunjuk Penggunaan Pupuk. Jakarta: Penebar Swadaya. 150 hlm.

Muslimin, M. Asmita, A. Anshor, M. dan Masyur, S. 2012. Dasar Dasar Ilmu Tanah,Program Studi Agroteknologi, Jurusan Ilmu Tanah,Fakultas Pertanian Universitas Hasanuddin. Makassar

Prasetyo, B.H., D.A. Suriadikarta. 2006. Karakteristik, potensi, dan teknologi pengelolaan tanah Ultisol untuk pengembangan pertanian lahan kering Indonesia. J. Litbang Pertan. 25:39-47.

Rachman, I.A., S. Djuniwati, K. Idris. 2008. Pengaruh Bahan Organik dan Pupuk NPK Terhadap Serapan Hara dan Produksi Jagung Di Inceptisol Ternate. J. Tanah Lingk. 10:7-13.

Rukmana, R. 1995. Bawang Daun. Yogyakarta: Kanisius.

Syukur, A dan N. M. Indah. 2006. Kajian Pengaruh Pemberian Macam PupukOrganik Terhadap Pertumbuhan Dan Hasil Tanaman Jahe Di InceptisolKaranganyar. Jurnal Ilmu Tanah Dan Lingkungan Vol 6 (2) : 124- 131

Winarso, S. 2016. Kesuburan Tanah, Dasar Kesehatan Dan Kualitas Tanah. Yogyakarta: Gava Media. 